\title{
Előadás-rekonstrukció, vagy amit akartok
}

A 20. századi magyar színháztörténeti kánon alakulása, szerk. JÁKfalvi Magdolna, Budapest, Balassi Kiadó, 2011.

Mi történhetett a múlt század magyar színpadain? Hogyan zajlottak azok a szóbeli emlékezet szerint legendás előadások, melyek a mai napig hatással vannak a színházi kommunikációra? Rekonstruálhatjuk-e őket, azaz emlékezeti, írásbeli vagy képi adatok alapján megidézhetjük-e a színpadon történteket? Illetve, ha a kellő mennyiségű dokumentumok ezt lehetővé teszik, milyen mértékben lenne véghez vihető a folyamat? Öszszeállítható-e a fellelt mozaikokból a teljes kép? A 20. századi magyar színháztörténeti kánon alakulása címü kötet önmeghatározása szerint a színházi múlt megírásának lehetőségeivel, dilemmáival foglalkozik, az elmúlt évtizedek emblematikussá vált előadásait veszi górcső alá. Elsősorban az 1970-80-as évek színpadi történéseit vizsgálja kiemelt figyelemmel, miközben próbát tesz a színi események és hatásmechanizmusaik rekonstruálására. A rekonstrukciók megkísérlői olyan húszas, harmincas éveikben járó szakavatott dramaturgok, színháztörténészek, akik a „legendás” előadásokról szóló szóbeli emlékezet tapasztalói, ám személyes élménnyel az adott színpadi eseményekről nem rendelkeznek. Ezáltal teremtenek meg egy sajátos vizsgálódási szerepvállalást, megpróbálnak objektív pozícióba helyezkedni a produkciók tanulmányozása során. A kötet a múltat idézi, ám szól a jelen színházának is, mivel felhívja a figyelmet a múlttá íródás mikéntjére, az archiválódás metódusára. Igaz, így némileg ellentmondásba kerül a színház alapvető természetével, jelenlétélményen alapuló pillanatnyiságával, ám a történeti perspektíva megköveteli ezt a metódust.

A kötet olyan lényeges kérdések válaszlehetőségeivel foglalkozik, mint például hogyan lehet színháztörténetet írni, továbbá hogyan és milyen mértékben lehet egy színházi előadást rekonstruálni. Jákfalvi Magdolna, a kötet szerkesztője kiemeli, hogy a rekonstrukciót elvégző szerzők elsődleges forrásnak az előadásokról készült mozgó- és állóképeket, továbbá a hanganyagokat tekintették, ám figyelembe vették a szóbeli történeteket, memoárokat, a színházi ügynökök jelentéseit, valamint a kritikai beszámolókat is. A gyüjteményes munka a vizsgálódások során magát az előadást tekinti alapegységnek, s célja, hogy ne az alkotók, hanem maguk a színrevitelek lépjenek párbeszédbe. Ezt az elgondolást már maga a kötet szerkezete is remekül érvényesíti, hiszen az elemzések címadása egyértelművé teszi: az adott fejezet például nem Shakespeare, hanem Paál István Hamletjét, nem Csehov, hanem Ascher Tamás Három nővérét taglalja - így értelemszerüen a rendezői koncepciók kerülnek előtérbe.

A kötetben elsőként a programadó előszót olvashatjuk, amelyben Jákfalvi összegzi a főbb felvetéseket, célkitűzéseket, majd ezt három színházelméleti tanulmány követi, legvégül, a harmadik egységben pedig tizennégy előadás-rekonstrukció kap helyet. 
A második szegmens tanulmányainak sorát Jákfalvi A dráma- és szinháztörténetírás, a kánon címü írása nyitja. Véleménye szerint a színházelméleti kutatások során történelem és fikció elemei összemosódnak, hiszen amennyiben egy előadásról nincs felvétel, megfelelö mértékü dokumentáció (amely önmagában sem volna elég, hiszen maga az előadás legfőbb „kelléke” a személyes tapasztalat), akkor sokkal inkább müködik a képzelet révén megalkotott konstrukció. Gondolatmenetében - a magyar drámatörténeti munkákkal történő számvetés során - említést tesz többek között Solt Andor, Hegedüs Géza, Galamb Sándor, Szigligeti Ede és Paulay Ede drámatörténeti elgondolásairól. Jákfalvi hosszasan elemzi Galamb drámatörténeti munkáját (Galamb Sándor, A magyar dráma története 1867-1896, I-II, Bp., MTA, 1973), hangsúlyozza a kötet legfőbb erényét, miszerint a drámák vizsgálata során a szerző figyelembe vette a teátrum közvetítő funkcióját, elsődleges kontextusba emelte azt, így teremtett kapcsolatot a színrevitelek között. Jákfalvi véleménye szerint a drámatörténeti munkáknak nem csupán elsődlegesen és helyenként kizárólagosan a szövegkiadást kellene vázolniuk - mint ahogy ez a metódus müködött általánosan az 1980-as évekig -, hanem vizsgálódásuk során kiemelt figyelmet kellene fordítani a színrevitelekre is. Tanulmányának következő egységében Jákfalvi az európai drámatörténet-írásra ható négy kánonalkotó müről ad összefoglalást (Peter Szondi: A modern dráma elmélete; Manfred Pfister: Das Drama; Eric Bentley: A dráma élete; Erika Fischer-Lichte: A dráma története). Olyan drámatörténet-írási módszert tart követendőnek, mely tudatában van annak, hogy archiválási tevékenysége már választást generál, a jelen szempontjából vizsgálja a múltat, továbbá történelemalkotásában fikcióképző. Végezetül pedig a dráma definíciói, drámaszöveg és színház kapcsolatai kerülnek összefoglalásra.

A kötet tanulmányainak sorát folytatja Kovács Krisztina $A$ szinész mint megfigyelö (A cenzúra müködése és a hatalomgyakorlás szintjei a magyarországi köszínházakban 1956 és 1962 között) című dolgozata. Kovács egy 1971-es, ismeretlen szerzőjü, az Országos Színháztörténeti Múzeum és Intézetben (OSZMI) található dokumentumot választ gondolatmenete vezérfonalául. Az említett mű az 1956 utáni, a hatalom által megfigyelt magyar színházi állapotokat taglalja. Kovács többek között bemutatja a színházi élet résztvevőinek '56-os tevékenységeit, azok következményeit, a kategorizálás rendszerét a színészek alkalmazhatóságát illetően, valamint a hatalom által kontrollált műsorpolitika mechanizmusát. A korszak színészügynökeinek jelentéseit elemezve arra a következtetésre jut, hogy a vizsgált időszakban a hatalom tekintete nem a színpad eseményeire, az előadások kettős beszédére szegeződött, sokkal inkább a színészek teátrumokon kívüli aktivitását, nyílt véleményformálását figyelte. Így a színpadon történtek nem kerültek dokumentálásra, az előadások rekonstruálására a jelentések nem hasznosíthatók. Kovács különös hangsúlyt fektet három színészügynök tevékenységére. Kiemeli a Cyránó fedőnévvel azonosított Szakáts Miklósnak a színházi kollégáiról és a nyugati országok követségeinek dolgozóiról, továbbá Bihari Éva álnévvel dolgozó Romhányi Gertrúdnak a disszidens színészekről, végezetül „Egri Dénesnek” a kecskeméti Katona József Színház alkalmazottairól készített jelentéseit. 
Boronkay Soma az 1930-as évek ünnepelt, ám a szocialista kultúrpolitika által feledtetett drámaírójáról, Meller Rózsiról szóló esettanulmányának kezdő sorai szerint „Meller Rózsi halott szerző. Nemcsak fizikai értelemben véve, hanem irodalomtörténetileg is." (41.) A tanulmány e tétel okait vizsgálja, és kísérletet tesz azok felszámolására, ahogyan portrét alkot a drámaíró személyéről, munkásságáról, illetve taglalja szövegeinek színreviteleit, azok nemzetközi és hazai kritikai fogadtatását. Boronkay elsődleges feladatának tekinti, hogy rekonstruálja Meller életművét, részletesen taglalja az Irja hadnagy, A zoinsdorfi asszonyok, A vallomás, a Dr. Barabás Irén és az Egy bála rizs című drámáit, továbbá előadásaikat.

A kötet harmadik szegmense tartalmazza az elmúlt század színpadi eseményeit idéző tizennégy előadás-rekonstrukciót. A vizsgált teátrumi produkciók időtávlati skálája 1930-tól 2004-ig terjed, kiemelve az 1970-80-as évek legendás produkcióit. Az elemzett előadásokra többnyire jellemző a szokványostól eltérő, újításra törekvő koncepció, Grotowski szegény színházának hatása, távolodás a hagyományos kőszínházak Brechtet és Sztanyiszlavszkijt idéző módszerétől. Kiemelt figyelemben részesülnek a kaposvári Csiky Gergely Színház és a kecskeméti Katona József Színház alkotásai, továbbá a meghatározó amatőr színházi csoportok, műhelyek. Az elemzések a fellelhető dokumentumok lehetőségeihez mérten különböző fokú rekonstrukciót hajtanak végre, valamint egy-egy hangsúlyozott vizsgálati szempont alapján idézik a színpadi történéseket az olvasó elé. Az alábbi bekezdések megpróbálják nagy vonalakban taglalni az elemzések főbb irányvonalait.

Első rekonstrukciós kísérletében Vincze Gabriella Madzsar Alice Bilincsek címü mozdulatművészeti előadását vizsgálja, amely 1930-ban került bemutatásra. Vincze Madzsar alkotói stílusát, a személye köré szerveződő mozdulatművészeti csoportot jellemzi, majd a produkciót a létrehozás, nem pedig a befogadás szempontjából taglalja. Mozgóképes dokumentáció a Bilincsekről nem készült, így elemzésében az alkotók visszaemlékezéseit, a létrehozás folyamatának dokumentumait használja fel, többek között a tornajegyzeteket, a koreográfia leírását, illetve Kozma Józsefnek a táncra vonatkozó jegyzeteket is tartalmazó kottáját. A rekonstruálási folyamatban részletesen vizsgálja a mozgásdráma jeleneteit, a táncmozdulatokat, a szimbólumokat, a jelmezeket, a zene, a fény és a színek jelenlétét, továbbá a térhasználatot.

Szabó-Székely Ármin Paál István Kömüves Kelemenjének 1973-as előadását tanulmányozza. Gondolatmenetében a rendezőnek és a Szegedi Egyetemi Színpad tagjának, Duró Győzőnek az alkotási folyamatot rögzítő visszaemlékezésére alapoz. Taglalja Grotowski szegényszínházának hatását Paál műveiben, és ennek megnyilvánulását a Kömüves Kelemenben. Elemzi többek között a színrevitel fény- és térhasználatát, a jelmezeket, a kellékeket, a hangok - a zajok és a zene - alkalmazását, a nézők helyzetét és számát, a színészi szereposztásokat. Lehetséges értelmezési távlatokat hoz létre a domináns jelenetek kiemelésével. Vizsgálja továbbá az általa lehetségesnek vélt politikai olvasatot, a kiváltott pszichikai hatást és a kritikai visszhangot.

Boronkay Soma Ruszt József 1974-ben a kecskeméti Katona József Színházban 
évadnyitóként bemutatott előadását, a Don Carlost a rendező munkásságának mestermüveként kezeli. Rekonstrukciójában hosszasan vizsgálja Ruszt szertartásos színházának elemeit, a vallás, a kereszténység auditív és vizuális megjelenítésének módszereit az adott darab példáján keresztül. Elemzi többek között a Grotowski-módszer hatásait, a nyitójelenet felépítettségét, a szerepértelmezéseket, a főbb szimbólumokat, a szereplöket, a térhasználatot.

Boross Martin a Szőke István rendezésében 1976-ban Kaposváron bemutatott Erdő címü előadás fekete-fehér videofelvételét követi végig szakavatott figyelemmel. Kiemeli a szcenika lényegi elemeit, továbbá a színház a színházban technikát, ezáltal az önreflexió mechanizmusát.

Zsámbéki Gábor 1977-es Ivanov előadásáról két gondolatmenetet követhetünk nyomon, Kálmán Mária és Marsalkó Eszter rekonstrukcióját. Kálmán kiemelt figyelemmel kezeli a szuicid motívumot, a karakterek vizsgálatát, a drámaszövegtől való eltéréseket, Zsámbéki realista formanyelvét, továbbá az előadásban megjelenő rendszerkritikát. Marsalkó az előadás kritikai reflexióinak szempontjait követi, elemzését pedig a Magyar Televízió felvételére alapozza. Említi többek között a térhasználat újszerüségét, kiemeli a díszletet, a lélektani realista játékmódot és a színen felsejlő abszurditást.

Schandl Veronika Paál István 1981-es szolnoki Hamletjét elemzi: tanulmányában elsőként rövid körképet kaphatunk a Kádár-korszak színházi cenzúrájáról, majd az amatőr színjátszó körök előadói szabadságát, Ruszt József és Paál István újító törekvéseit vizsgálja. Schandl gondolatmenetét a színház által kiadott rendezőpéldányra alapozza. A drámaszövegtől való eltéréseket a politikai rendszerre irányuló reflexiókként kezeli. Schuller Gabriella tanulmányában górcső alá kerül az 1981-es Marat/ Sade című darab színrevitele Ács János rendezésében. Schuller bevezetésként a korabeli színházi műsorterv hatalom általi elfogadtatásának procedúráját tárja az olvasó elé, majd hosszasan elmélkedik az előadás politikai olvasatáról, továbbá arról a mechanizmusról, amely által az '56-os eseményeket idéző produkció „politikai misévé” (128.) vált. Kristóf Borbála rekonstrukciója Gothár Péter 1984-es kaposvári Diótörő-előadását választja témájául, mely a rendező szavait idézve: „tökéletesen infantilis színházi téboly”. (135.) A tanulmány a színrevitel politikai kettős beszédének lehetőségeit elemzi, s a lezárásból visszatekintve jól kirajzolódik az 1980-as évek előadásainak rekonstrukcióiból a rendezések politikai értelmezésének lehetősége.

A múlt évtized előadásai közül Zsótér Sándor Csongor és Tündéjének (2004) színpadi világát idézi Timár András a kötet utolsó tanulmányában. Fókuszba emeli azt a lényegi kérdést, miszerint hogyan lehetséges Vörösmarty szövegének kiszabadítása a kanonizált könyvdrámai fogságból, mi módon alkotható újra a dráma a színpadon.

A 20. századi magyar színháztörténeti kánon alakulása címü kötet hiánypótló mü, amely egy átfogó színháztörténeti kutatás kezdeti lépéseinek eredményeit rögzíti. Az elmúlt század kánonalkotó előadásaiból válogatva próbálja a felelhető információrészletek összeillesztésével megidézni a korszak újító színpadi történéseit. Lehetö- 
ségeihez mérten a mű a fókuszba állított előadások minél teljesebb történetét követi nyomon a próbafolyamatoktól kezdve egészen a kritikai fogadtatásokig. Az alkotók személyes beszámolóit használva teszi élővé a múlt színpadi történéseit. A kötet úttörő jelleggel vázol fel és müködtet elemzéseiben egy lehetséges színháztörténet-írási metódust: re/konstruálja a múlt színházát. 